\title{
Correction to: The health-related quality of life in Iranian patients with COVID-19
}

Cyrus Alinia', Safura Yaghmaei ${ }^{2}$, Farman Zahir Abdullahn ${ }^{3}$, Asad Ahmadi ${ }^{4}$, Nasrin Samadi ${ }^{5}$, Sima Pourteimour $^{6}$, Hossein Safari ${ }^{7}$, Hassan Mahmoodi ${ }^{4}$, Ghobad Moradi ${ }^{4}$ and Bakhtiar Piroozi ${ }^{4^{*}}$

Correction to: BMC Infect Dis 21, 459 (2021)

https://doi.org/10.1186/s12879-021-06170-z

After publication of the original article [1], an error was identified in two authors' names.

The incorrect names are:

Sima Pourteymour;

Hassan Mahmoudi

The correct names are:

Sima Pourteimour;

Hassan Mahmoodi

The original article has been corrected.

\begin{abstract}
Author details
'Department of Health Management and Economics, School of Public Health, Urmia University of Medical Sciences, Urmia, Iran. ${ }^{2}$ Nursing Care Research Center, Semnan University of Medical Sciences, Semnan, Iran. ${ }^{3}$ Special Education Department, College of Education and Language, Charmo University, Chamchamal, Kurdistan Region, Iraq. ${ }^{4}$ Social Determinants of Health Research Center, Research Institute for Health Development, Kurdistan University of Medical Sciences, Sanandaj, Iran. ${ }^{5}$ Student Research Committee, Urmia University of Medical Sciences, Urmia, Iran. 'Department of Nursing, School of Nursing and Midwifery, Semnan University of Medical Sciences, Semnan, Iran. ${ }^{7}$ Health Promotion Research Center, Iran University of Medical Science, Tehran, Iran.
\end{abstract}

Published online: 07 June 2021

\section{Reference}

1. Alinia C, et al. The health-related quality of life in Iranian patients with COVID-19. BMC Infect Dis. 2021;21:459 https://doi.org/10.1186/s12879-02106170-z.

The original article can be found online at https://doi.org/10.1186/s12879021-06170-z

* Correspondence: bpiroozi@gmail.com

${ }^{4}$ Social Determinants of Health Research Center, Research Institute for Health Development, Kurdistan University of Medical Sciences, Sanandaj, Iran

Full list of author information is available at the end of the article

(c) The Author(s). 2021 Open Access This article is licensed under a Creative Commons Attribution 4.0 International License, which permits use, sharing, adaptation, distribution and reproduction in any medium or format, as long as you give appropriate credit to the original author(s) and the source, provide a link to the Creative Commons licence, and indicate if changes were made. The images or other third party material in this article are included in the article's Creative Commons licence, unless indicated otherwise in a credit line to the material. If material is not included in the article's Creative Commons licence and your intended use is not permitted by statutory regulation or exceeds the permitted use, you will need to obtain permission directly from the copyright holder. To view a copy of this licence, visit http://creativecommons.org/licenses/by/4.0/. The Creative Commons Public Domain Dedication waiver (http://creativecommons.org/publicdomain/zero/1.0/) applies to the data made available in this article, unless otherwise stated in a credit line to the data. 